23 Rohadatul Aisy : Effect Of Mangrove Leaf Extract Dosage Rhizophora Mucronata Lmk. On The Viability

\title{
Effect Of Mangrove Leaf Extract Dosage Rhizophora Mucronata Lmk. On The Viability Of Hela Cells
}

\author{
Rohadatul Aisy*, Bambang Budi Sasmito \\ Faculty of Fisheries and Marine Sciences Universitas Brawijaya. \\ *Corresponding author: rohadatul_aisy@student.ub.ac.id
}

\begin{abstract}
This study aims to determine the IC50 value of the mangrove leaf extract type Rhizophora mucronata Lmk. against the viability of Hela cells. The samples extracted with three types of solvents were previously conducted preliminary research on phytochemical compounds and their toxicity values with the Meted Brine Shrimp Letality Test (BSLT). In the toxicity test, the highest level of toxicity was obtained in the ethanol extract with a value of $166.72 \pm 7.72 \mathrm{ppm}$, then the sample was continued for the cytotoxicity test using the MTT method. The dosage variants used in this study were 62.5 ppm; 125 ppm; 250 ppm; 500 ppm; and $1000 \mathrm{ppm}$. The variation in dosage shows an effect on the viability of Hela cells, namely a decrease in the percentage of living cells along with the addition of the ethanol extract dose of Rhizophora mucronata Lmk leaves. which is given. And the IC50 value obtained from this study was $63.67 \mu \mathrm{g} / \mathrm{mL}$ with the toxic category
\end{abstract}

\section{Keywords: Cells Hela, Anticancer, Rhizophora Mucronata, Cytotoxicity}

\section{INTRODUCTION}

Cancer is a body tissue cell that becomes malignant, which is characterized by rapid cell division that cannot be controlled to form similar cells. Cancer cells themselves are similar to the original cells with a primitive and imperfect shape. Antiproliferative signals found in normal cells generally function to maintain cell regularity and hemostasis in tissues, therefore cancer cells themselves cannot control cell cycles and hemostatic function, this can cause cancer cells to continuously proliferate and form abnormal tissues (Darma)., et al. 2009).

The most common cancers suffered by women are breast cancer and cervical cancer. Cervical cancer itself ranks second as the most common cancer after breast cancer, and ranks third as the cause of cancer death. Based on data from the World Health Organization or WHO (2014), there were up to more than 270,000 women who died due to cervical cancer and $85 \%$ came from developing countries (ICO, 2019).

For now, according to Sukmarianiti, et al. (2013), there is still no ideal drug that can damage cancer cells without damaging normal cells. For chemotherapy treatment itself in cancer patients generally consists of a combination of surgery and radiation. However, chemotherapy treatment itself has many side effects, so further research is needed on bioactive compounds from natural ingredients that can be used as cancer drugs 
which are expected to have fewer side effects. As well as research on the content of mangrove plants.

Mangroves are plants that live on the coast which is located in tidal waters of the tropics and sub-tropics. Therefore, the mangrove ecosystem is also commonly referred to as coastal forest, tidal forest, brackish forest or mangrove forest. The mention of mangroves itself is taken from one of the names of mangrove species, namely Rhizophora sp (Edi, et al. 2009).

According to Faoziyah and Kurniawan (2017), mangroves contain several chemical compounds including phenolic compounds and other phytochemical compounds such as alkaloids, steroids, saponins, flavonoids and tannins. From the research that has been done previously, the leaves of the mangrove plant Rhizophora mucronata Lmk. has been tested in

\section{METHODS}

\section{Tools and materials}

The tools used are digital scales, rotary evaporator, $\mathrm{CO}_{2}$ incubator, UV lamp, laminar air flow cabinet, tissue culture flask, conical tube, microplate 96 wells, haemocytometer, magnetic stirrer, pipetman, yellow tip, blue tip, vortex, microscope., eppendrop tube, and ELISA reader.

The materials used in this study were mangrove leaves of the Rhizhopora mucronata Lmk species. Obtained from Permata Pilang Beach located in Pilang, Kec. Kademangan, Probolinggo City, East Java. Other materials used were n-Hexane solvent, ethyl acetate, 70\% vitro and proven to be able to inhibit the growth of cancer cells.

To determine the pharmacological effects and toxicity of Rhizophora mucronata Lmk mangrove extract. it is necessary to carry out a cytotoxic test. Cytotoxic test is an in vitro toxicity test with cell culture which is used to detect the presence or absence of antiviability activity of a compound. Cytotoxic test is a quantitative test by detecting cell death. The parameter used in the cytotoxic test is the $\mathrm{IC}_{50}$ value. This $\mathrm{IC}_{50}$ value is a value that indicates the concentration of a compound that produces a cell viability barrier of $50 \%$ and can be used to determine the effect of a compound contained in the cell. The $\mathrm{IC}_{50}$ value is also able to show the ability of a compound as a cytotoxic. The smaller the $\mathrm{IC}_{50}$ value, the more toxic the compound. Cytotoxic test can also be used to determine the extent to which cells are able to survive

ethanol, RPMI (Rosewell Park Memorial Institute) 1640 (Sigma) media, 1\% PenicillinStreptomycin (Gibco), Fungison 0.5\% (Gibco), FBS ( Fetal bovine serum), Trypsin-EDTA $0.25 \%$ in PBS, NaHCO3 (Sigma) and HEPES (N2-hydroxyethyl piperazine-N-2ethanesulfonic acid) (Sigma), Trypan blue, DMSO solution as extract solvent, MTT, Reagent stopper (10\% sodium dodecyl sulfate).

Samples of Rhizophora mucronnata Lmk mangrove leaf powder resulting from the drying process with the air-dried method were then extracted by graded maceration method using 
three types of solvents, namely, n-hexane, ethyl acetate and ethanol with a ratio of solvent and leaf powder sample of 1:2.

\section{Phytochemicals}

Extracts of n-hexane, ethyl acetate and ethanol from mangrove leaves Rhizophora mucronata Lmk. tested the content of secondary metabolites of flavonoids, alkaloids, tannins, saponins, steroids/triterpenoids.

\section{Toxicity}

Toxicity test was carried out using the BSLT (Brine Shrimp Letality Test) method, the test solution was made with concentrations of 1000 ppm, 100 ppm, 10 ppm, 1 ppm with 0 ppm as a control. The test was carried out by inserting $5 \mathrm{ml}$ of the test solution into the vial and then adding $10 \mathrm{~A}$. salina larvae that were 48 hours old. The vial was placed under a lamp and allowed to stand for 24 hours after which the live/dead larvae were observed.

\section{Cytotoxic}

Hela cell preparation was carried out by taking Hela cells from the liquid nitrogen tank and then diluting them at $37^{\circ} \mathrm{C}$, then spraying the ampoules using $70 \%$ ethanol, the cells were centrifuged at $1500 \mathrm{rpm}$ for 15 minutes, the sediment from the centrifuge was added to RPM 1640- serum. Then put the cell suspension into a small tissue culture flask and observed under a microscope. Cells that are still alive have the characteristics of being round, clear and shining. After that, the cells were placed in a flask and incubated in an incubator with a temperature of $37^{\circ} \mathrm{C}$ with $\mathrm{CO}_{2}$ gas irrigated.
Make a test solution by making a stock solution beforehand from $25 \mathrm{mg}$ of Rhizophora mucronata Lmk mangrove leaf extract with RPMI 1640 and Pen-Strep media. This results in a stock solution of $25,000 \mu \mathrm{g} / \mathrm{mL}$. From the stock solution, a series of concentration solutions with a concentration of 1000 was made; 500; 250; 125; and $62.5 \mu \mathrm{g} / \mathrm{ml}$.

The cytotoxic test method used is the MTT method. First distribute the cells onto a 96-well plate. and incubated for 24 hours so that the cells stick to the bottom wall of the well. In each well that has been given a cell, then a sample solution with various concentrations is added, cell control and media control. After that, it was re-incubated for 24 hours. After the incubation period, discard the test solution and rinse the wells three times using $100 \mu \mathrm{g} l$ of PBS. Then $10 \mu \mathrm{g}$ MTT $5 \mathrm{mg} / \mathrm{ml}$ was added to the well. Then incubated again for 4 hours at a temperature of $37^{\circ} \mathrm{C}$. Then the living cells will metabolize MTT to form purple formazan. After formazan was formed, then 100 $\mu \mathrm{g}$ of $10 \%$ SDS stopper reagent was added in $0.01 \% \mathrm{HCl}$ in order to stop the MTT reaction, which was then re-incubated overnight, during the incubation process the cells were covered with aluminum foil. Then read the absorption using an ELISA reader at a wavelength of $550 \mathrm{~nm}$. After that count the number of cells that are still alive with the formula:

$\%$ live cells $=\frac{\text { OD Treatment }- \text { OD Media }}{\text { ODCell Control-OD Media }} \times 100 \%$ 


\section{RESULT AND DISCUSSION}

\section{Phytochemicals}

Phytochemical tests are included in the qualitative test carried out with the aim of knowing the bioactive components contained in the sample. According to (Simaremare, 2014), phytochemical testing was carried out based on color changes that occurred after the addition of color reagents.

Table 1. Phytochemical test results

\begin{tabular}{lccc}
\hline Information & $\begin{array}{c}\text { n- } \\
\text { Heksan }\end{array}$ & $\begin{array}{c}\text { Ethyl } \\
\text { acetate }\end{array}$ & Ethanol \\
\hline Saponin & + & - & + \\
Steroid/Trit & + & + & + \\
erpenoid & & & \\
Flavonoid & + & - & + \\
Tanin & - & - & +
\end{tabular}

Source: Research Results, 2020

In Table 1, the test results are obtained. The phytochemicals showed that the samples extracted using n-hexane and ethanol had more positive compounds than samples extracted with ethyl acetate solvent. Because each plant contains different phytochemicals, the solubility of the compound cannot be determined with certainty. In addition, there are also disadvantages of this phytochemical screening, namely it can give false positive results. So some compounds contained in the sample can show positive results even though the compound in question is not present in the sample. There is also another possibility that can occur, namely due to a mixture of several colors resulting from the addition of reagents which then show positive results (Endarini, 2016).

\section{Toxicity}

Toxicity testing was conducted to determine the toxic effect caused by a single dose of a mixture of chemicals on test animals as a prescreening test for anticancer bioactive compounds. the result of the toxicity test is the $\mathrm{LC}_{50}$ (Lethal concentration) value of the test extract or it can be said that the amount of concentration of the test extract that can cause death in $50 \%$ of test animals after incubation for 24 hours. the compound can be considered active if the $\mathrm{LC}_{50}$ value is $<1000 \mathrm{ppm}$ (Jelita, et al. 2020). The results of the BSLT test can be seen in Table 2.

Table 2. BSLT Test

\begin{tabular}{lcc}
\hline Sample & $\begin{array}{c}\text { IC50 value } \\
\text { nilai } \\
\boldsymbol{\mu g} / \mathbf{m L}\end{array}$ & Category toxicity \\
\hline n-Heksan & $361,26 \pm 101,7$ & Toxic \\
Ethyl acetate & $1341,83 \pm 350,9$ & Not \\
Ethanol & $166,72 \pm 7,72$ & Toxic
\end{tabular}

Source: Research Results, 2020

In the toxicity test, the $\mathrm{LC}_{50}$ value indicates the level of toxicity of a material, where the higher the toxicity level of a material, the lower the $\mathrm{LC}_{50}$ value. According to Supriningrum, et al. (2016), the sample became toxic because it contained flavonoid compounds that could cause Stomach poisoning (stomach poison) to test larvae and the ability of flavonoid compounds that have antioxidant and anticancer effects. For samples with the highest toxicity, the toxicity test is continued. 


\section{Cytotoxic}

Based on the results of the preliminary toxicity test, samples with toxicity content were obtained in the ethanol extract. So in the cytotoxic test that was tested on Hela cells, ethanol samples were used. Based on the explanation of Arel, et al. (2018), cytotoxicity is the ability of a compound that can induce the death of a cell. Where the desired cell death is programmed death or apoptosis. While the cytotoxicity test based on the explanation of Rohmah, et al. (2019), is a test used to find information about drug concentrations that allow a cell to survive. So the cytotoxicity test can show specifically how the changes in a cell.

Susilowati, et al. (2012), cell morphology Hela after dosing treatment showed that the living cells were spherical in shape, colonized and semi attached to the media. While the dead cells are round but floating.

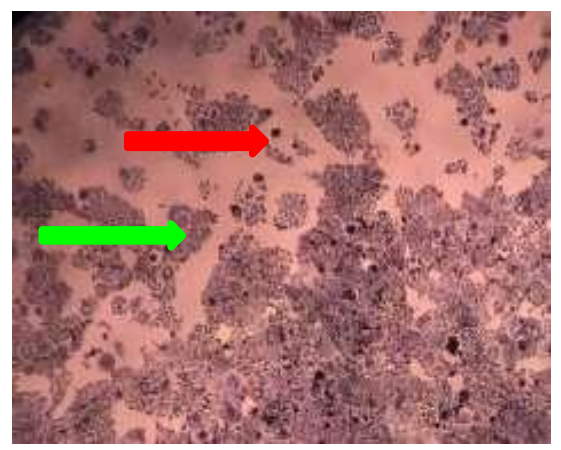

Figure 1. Hela cell morphology

Caption:

- Red arrows indicate dead cells

- Green arrows indicate live cells

In the cytotoxicity test, the data obtained is in the form of percent of cell life which can later be used to determine the value of $\mathrm{IC}_{50}$ (Inhibitor concentration) or levels that can inhibit cell proliferation by $50 \%$. Determination of $\mathrm{IC}_{50}$ value using linear regression between log dose and percent cell life. With the $\mathrm{IC}_{50}$ value, it can determine the potential cytotoxicity of the test extract on cells, besides that the $\mathrm{IC}_{50}$ value is a benchmark value that will be used as a cell kinetics test.

Based on Figure 2. Linear Regression Equation Between Log Dose and \% Viability, it can be seen. The results showed that there was a decrease in the percentage of living cells along with the addition of the dose of ethanol extract of Rhizophora mucronata Lmk mangrove leaves. which are given.

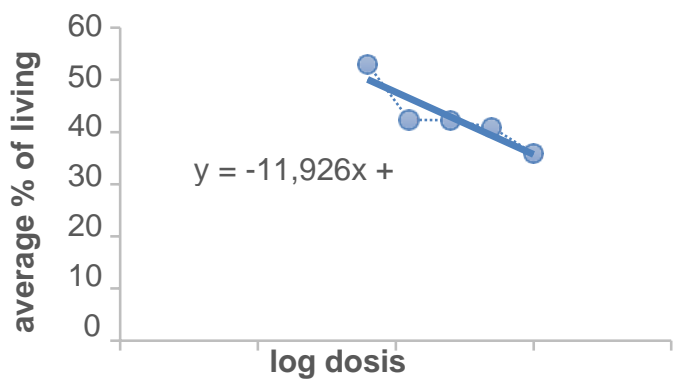

Figure 2. Linear Regression Equation Between Log Dose and \% Viability

With a linear equation between the dose $\log$ and $\%$ viability of Hela cells in this study, the equation $\mathrm{y}=-11.926 \mathrm{x}+71.517$ was obtained which was then entered into the formula $y=50$, the value for $\mathrm{IC}_{50}$ was $63.67 \mu \mathrm{g} / \mathrm{mL}$. Based on the opinion expressed by Weerapreeyakul, et al. (2012), the level of cytotoxic compounds can be grouped into three categories, namely the $\mathrm{IC}_{50}$. value $<10 \mu \mathrm{g} / \mathrm{mL}$ very toxic, $\mathrm{IC}_{50}<10-100$ $\mu \mathrm{g} / \mathrm{mL}$ toxic and $\mathrm{IC}_{50}<100-500$ less toxic. Based on this statement, it can be concluded that the ethanol extract of Rhizophora mucronata Lmk mangrove leaves has a cytotoxic effect in the 
category of toxic to Hela cells. So it has potential as an anticancer drug. The toxic nature of the test extract on Hela cells is probably caused by secondary metabolites that have anticancer

\section{CONCLUSION}

Ethanol extract of samples of Rhizophora mucronata Lmk mangrove leaves given to Hela cells with different doses had an effect on the level of viability and proliferation, where increasing the dose to Hela cells caused a decrease in the percentage of living cells. The lowest percentage value of living cells was given to the dose of ethanol extract of the Rhizophora

\section{REFERENCES}

Arel, A., Epi, S. W. \& Yolanda, O. (2018). Profil Metabolit Sekunder Ekstrak Daun Berenuk (Crescentia cujeti L.) dan Uji Sitotoksik Dengan Metode Brine Shrimp Lethality Test. Jurna Katalisator. 3(2), $82-88$, http://ejournal.kopertis10.or.id/index.ph $\mathrm{p} /$ katalisator.

Darma, A. P., Rosana, A. A., Perdana, A. N., Ameilinda, M., Ilham, A. F., Adam,H. \& Edy M. (2009). Aktivitas Sitotoksik Ekstrak Etanol Herba Ciplukan (Physalis angulata L.) Pada Sel Kanker Leher Rahim HeLa Melalui Modulasi Ekstrak Protein p53.

Edi, M., Okik Hendriyanto, C. \& Nur, F. (2009). Konservasi Hutan Mangrove Sebagai Ekowisata. EnvirotekJurnal Ilmiah Teknik Lingkungan, 1, 51-57. properties contained in the test extract. These secondary metabolites include flavonoids (quercetin), alkaloids, tannins, saponins and terpenoids.

mucronata Lmk mangrove leaf sample at a concentration of $1000 \mathrm{ppm}$ with a value of $35.9 \%$. And obtained the $\mathrm{IC}_{50}$ value of $63.67 \mathrm{ppm}$. So it can be seen that the ethanol extract of Rhizophora mucronata Lmk mangrove leaf powder is toxic and has the potential as anticancer because the $\mathrm{IC}_{50}$ value is included in the toxic category, namely $\mathrm{IC}_{50}>10-100 \mu \mathrm{g} / \mathrm{mL}$.

Endarini, L. H. (2016). Farmakognisi dan fitokimia. jakarta.

Faoziyah, A. R. \& Kurniawan, W. (2017). Pemanfaatan Ekstrak Daun Mangrove (Rhizophora mucronata sp.) Dengan Variasi Pelarut Sebagai Bahan Aktif Sediaan Farmasi Terapi Anti Kanker. Journal of Health, 4(2), 68-74. doi: 10.30590/vo14-no2-p68-74.

ICO. (2019). Human Papillomavirus and Related Diseases Report. 1-67.

Jelita, S. F., GIta, W. S., Michella, F., Ade, Z. \& Sandra, M. (2020). Uji Toksisitas Infusa Acalypha Siamenziz Dengan Metode Brine Shrimp Lethality Test (BSLT). Jurnal Farmaka, 18(1), 14-22.

Rohmah, J., Rini, C. S. \& Wulandari, F. E. (2019). Uji Aktivitas Sitotoksik Ekstrak Selada Merah (Lactuca sativa var. Crispa) Pada Berbagai Pelarut Ekstrak 
Dengan Metode BSLT (Brine shrimp letality test). 4(1), 18-32.

Simaremare, E. S. (2014). Skrining Fitokimia Ekstrak Etanol Daun Gatal (Laportea decumana (Roxb.) Wedd). Pharmacy, 11(1), 98-107.

Sukmarianiti, N. W. S., Suaniti, N. M. dan Swantara, I. M. D. (2013). Identivikasi dan Uji Aktivitas Antikanker Ekstrak Spons Ianthella Basta Terhadap Larva Artemia Salina L. Cakra Kimia, 1(1), 14-19.

Supriningrum, R., Sapri \& Pranamala, V. (2016). Uji Toksisitas Akut Ekstrak Etanol Akar KB (Coptosapelta tomentosa valeton ex. K.Heyne) Dengan Metode Brine Shrimp Lethality
Test (BSLT). Jurnal Ilmiah Manuntung, 2(2), 161-165.

Susilowati, S., Claresa, A. \& Arifin, I. (2012). Uji Sitoksisitas Fraksi N-Heksan Ekstrak Etanol Herba Alfalfa (Medicago sativa L.) Pada Sel T47D dan Sel Hela Serta Identifikasi Kandungan Senyawa Kimia. Jurnal Ilmu Farmasi \& Farmasi Klinik, 1-9.

Weerapreeyakul, N., Apiyada, N., Sahapat, B., Thaweesak, T. \& Bungorn, S. (2012). Evaluation Of The Anticancer Potential Of Six Herbs Against A Hepatoma Cell Line. Chinese Medicine (United Kingdom), $\quad$ 7(15), 1-7. Doi: 10.1186/1749-8546-7-15. 